\title{
Antigen presentation by $\mathrm{MHC}$-dressed cells
}

\author{
Masafumi Nakayama* \\ Frontier Research Institute for Interdisciplinary Sciences, Tohoku University, Sendai, Japan
}

\section{Edited by:}

Stephanie Hugues, University of Geneva, Switzerland

\section{Reviewed by:}

Graham Taylor, University of Birmingham, UK

Laurence C. Eisenlohr, Thomas Jefferson University, USA

Jürgen Wittmann, University of

Erlangen-Nürnberg, Germany

\section{*Correspondence:}

Masafumi Nakayama, Frontier

Research Institute for Interdisciplinary

Sciences, Tohoku University, 6-3

Aramaki-Aoba, Aoba-ku, Sendai

980-8578, Japan

e-mail:mnakayama@fris.tohoku.ac.jp
Professional antigen-presenting cells (APCs) such as conventional dendritic cells (DCs) process protein antigens to $\mathrm{MHC}$-bound peptides and then present the peptide-MHC complexes to $T$ cells. In addition to this canonical antigen presentation pathway, recent studies have revealed that DCs and non-APCs can acquire $\mathrm{MHC}$ class I (MHCl) and/or MHC class II (MHCII) from neighboring cells through a process of cell-cell contact-dependent membrane transfer called trogocytosis. These MHC-dressed cells subsequently activate or regulate $\mathrm{T}$ cells via the preformed antigen peptide- $\mathrm{MHC}$ complexes without requiring any further processing. In addition to trogocytosis, intercellular transfer of $\mathrm{MHCl}$ and $\mathrm{MHCll}$ can be mediated by secretion of membrane vesicles such as exosomes from APCs, generating MHC-dressed cells. This review focuses on the physiological role of antigen presentation by $\mathrm{MHCl}$ - or $\mathrm{MHCll}$-dressed cells, and also discusses differences and similarities between trogocytosis and exosome-mediated transfer of MHC.

Keywords: intercellular communication, trogocytosis, exosomes, dressing, MHC

\section{INTRODUCTION}

Intercellular transfer of MHC was first observed by Cone et al. over 40 years ago (1). In this study, mouse $\mathrm{T}$ cells were adoptively transferred to MHC-mismatched mice, and the authors surprisingly found the MHC of the recipient mice on transferred T cells (1). Since this seminal study, numerous others have shown that the $\mathrm{T}$ cell receptor (TCR) rapidly (within minutes) acquires MHC molecules from antigen-presenting cells (APCs) via the immunological synapse formed at cell-cell contact area, and that this phenomenon impacts $\mathrm{T}$ cell activation (2-8), although the physiological relevance of this is still not fully understood. This intercellular transfer of plasma membrane has been called absorption, acquisition, nibbling, shaving, snatching, stripping, or trogocytosis, which is from the ancient Greek Trogo, meaning "gnaw" $(9,10)$. Among these names, trogocytosis is now most commonly used. Several recent studies reported that trogocytosis of MHC class I (MHCI) and MHC class II (MHCII) occurs not only between $\mathrm{T}$ cells and APCs, but between a wide variety of cell types including APCs-APCs, APCs-natural killer (NK) cells, tumor cells-T or NK cells, etc. (10-14), suggesting that the type of cell receiving such MHC may impact antigen-specific $\mathrm{T}$ cell activation.

Intercellular transfer of MHC is mediated not only via trogocytosis but also via exosomes, which are nano-sized membrane vesicles released from various cells $(12,15)$. Because trogocytosis generally occurs rapidly in a cell-cell contact-dependent manner, it has been considered to be a distinct mechanism from exosome release $(9,16)$, although some aspects of trogocytosis and exosome-mediated transfer are quite similar, as described below.

Trogocytosis- or exosome-mediated intercellular MHC transfer can transiently generate MHC-dressed cells, which modulate T cell activation (Table 1). For example, $\mathrm{CD}_{8}{ }^{+}$cytotoxic $\mathrm{T}$ lymphocytes (CTLs) dressed with APC-derived MHCI are lysed by neighboring CTLs $(2,4) . \mathrm{CD}^{+} \mathrm{T}$ cells dressed with dendritic cell (DC)-derived
MHCII work as suppressor APCs $(17,18)$. These reports suggest that DC-derived MHC molecules are functional on T cells (Table 1), although some MHC molecules may be occupied by the TCR. Likewise, DCs also acquire MHC molecules from neighboring DCs, and the transferred MHC molecules are functional on the recipient DCs. Because recent findings on T cells dressed with MHC is well summarized by other review papers $(11,14)$, this review focuses on the DCs or non-professional APCs dressed with MHCI or MHCII, which acquire APC-like function, and also discusses the differences and similarities between trogocytosis and exosome-mediated transfer.

\section{ANTIGEN PRESENTATION BY MHCI-DRESSED CELLS: CROSS-DRESSING}

Dendritic cells have long been known to present MHCI-bound antigens to $\mathrm{CD} 8^{+} \mathrm{T}$ cells through two main pathways: direct presentation of endogenous viral antigens when DCs are virally infected (Figure 1A), and cross-presentation of exogenous antigens from dying tumor cells and virally infected cells that are phagocytosed and processed $(57,58)$ (Figure 1B). In addition to these canonical antigen presentation pathways, several recent studies proposed a third pathway of antigen presentation in which DCs acquire the preformed peptide-MHCI complexes from neighboring DCs or tumor cells and activate $\mathrm{CD}^{+} \mathrm{T}$ cells without any further peptide processing $(28,29,35,36,59,60)$ (Figure 1C). This third pathway of antigen presentation was coined "cross-dressing" by Yewdell and Haerfar (61). Although the antigen presentation by DCs dressed with MHCII is also called cross-dressing in some papers $(55,56)$, this original meaning seems to be the dressed MHCI-mediated antigen presentation (61). Dolan et al. clearly demonstrated the existence of the cross-dressing pathway both in vitro and in vivo (35). Specifically, it was shown that when $\mathrm{H}$ $2^{\mathrm{q}}$ mouse bone marrow-derived DCs (BMDCs) were co-cultured with dying $\mathrm{H}-2^{\mathrm{b}}$ tumor cell lines expressing ovalbumin (OVA), 
Table 1 | Overview of intercellular MHC transfer

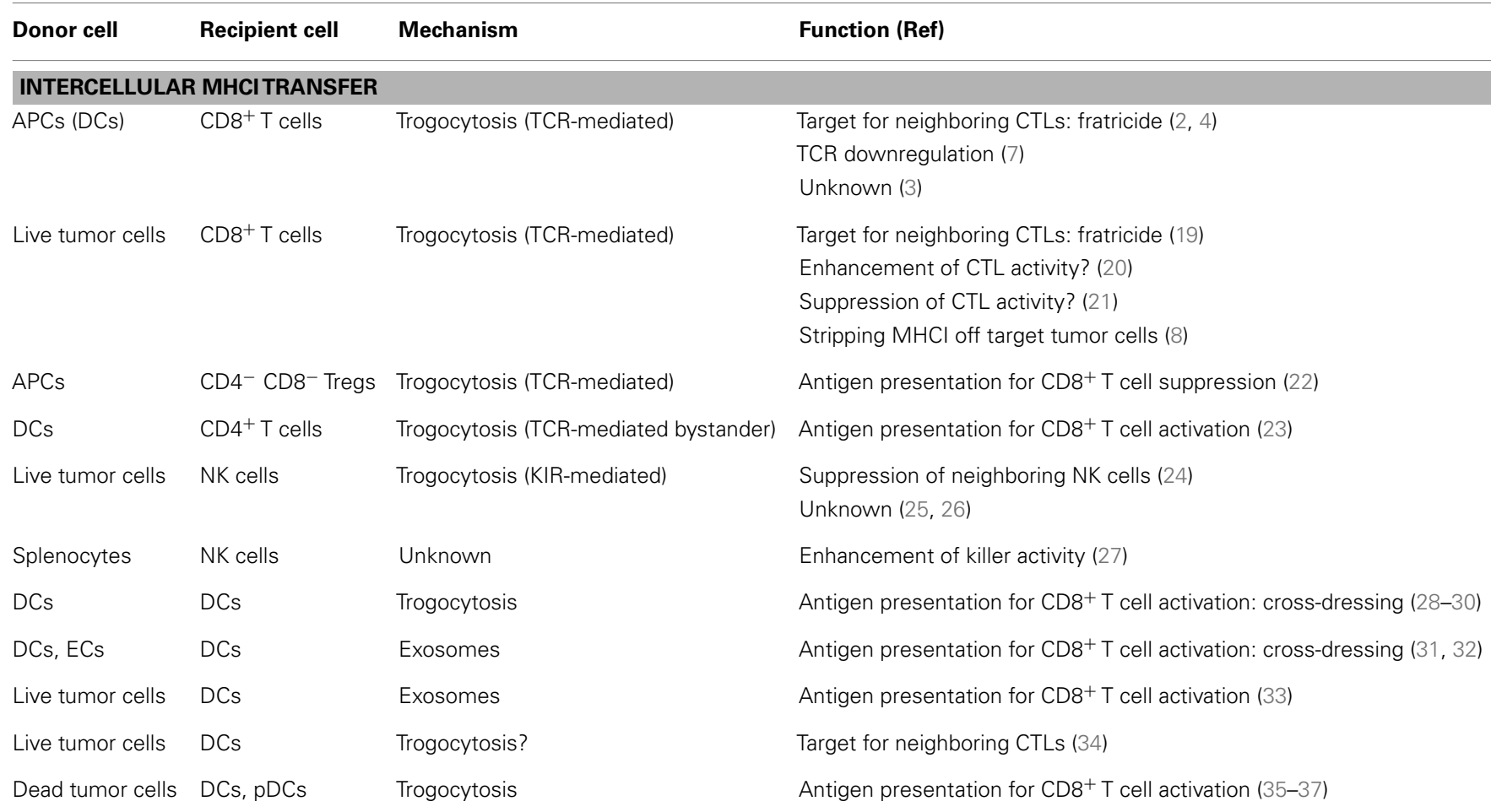

\section{INTERCELLULAR MHCIITRANSFER}

$\begin{array}{lll}\text { mTECs } & \text { Thymic DCs } & \text { Unknown } \\ \text { APCs (DCs) } & \text { CD4 }{ }^{+} \text {T cells } & \text { Trogocytosis (TCR-mediated) }\end{array}$

Antigen presentation for central tolerance (38-40)

Sustaining of TCR signaling $(41,42)$

Antigen presentation for $\mathrm{CD} 4^{+} \mathrm{T}$ cell suppression $(17,18)$

Antigen presentation for $\mathrm{CD}^{+}{ }^{+} \mathrm{T}$ cell activation (43-45)

APCs (DCs) $\quad$ CD4 $4^{+}$cells $\quad$ Exosomes

Antigen presentation for $\mathrm{CD}^{+} \mathrm{T}$ cell suppression $(46,47)$

Unknown (48)

\begin{tabular}{|c|c|c|c|}
\hline APCs & CD4 ${ }^{+}$Tregs & Trogocytosis (TCR-mediated) & Antigen presentation for $\mathrm{CD} 4^{+} \mathrm{T}$ cell suppression (44) \\
\hline DCs & $\mathrm{CD}^{+} \mathrm{T}$ cells & Trogocytosis (TCR-mediated bystander) & Antigen presentation for $\mathrm{CD} 4^{+} \mathrm{T}$ cell activation? $(3,49)$ \\
\hline DCs & NK cells & Trogocytosis & Antigen presentation for $\mathrm{CD} 4^{+} \mathrm{T}$ cell suppression (50) \\
\hline DCs & ILC2s & Trogocytosis & Antigen presentation for $\mathrm{CD} 4^{+} \mathrm{T}$ cell activation (51) \\
\hline DCs & LNSCs & Trogocytosis and exosomes & Antigen presentation for $\mathrm{CD} 4^{+} \mathrm{T}$ cell suppression (52) \\
\hline DCs & DCs & Exosomes & Antigen presentation for $\mathrm{CD} 4^{+} \mathrm{T}$ cell activation $(31,53,5$ \\
\hline Dead tumor cells & DCs & Trogocytosis? & Antigen presentation for $\mathrm{CD} 4^{+} \mathrm{T}$ cell activation (55) \\
\hline APCs & DCs & Unknown & No antigen-presenting activity (56) \\
\hline
\end{tabular}

APCs, antigen-presenting cells; CTLs; cytotoxic T lymphocytes; DCs, dendritic cells; ECs, endothelial cells; ILC2s, group 2 innate lymphoid cells; KIR, killer cell immunoglobulin-like receptor; LNSCs, lymph node stromal cells; MHCl, MHC class I; MHCIl, MHC class II; mTECs, medullary thymic epithelial cells; NK, natural killer; pDCs, plasmacytoid DCs; TCR, T cell receptor; Tregs, regulatory $T$ cells.

the $\mathrm{H}-2^{\mathrm{q}}$ BMDMs acquired the OVA peptide- $\mathrm{H}-2 \mathrm{~K}^{\mathrm{b}}$ complexes from the tumor cells, and subsequently activated OT-I CD8 ${ }^{+}$ $\mathrm{T}$ cells expressing the TCR that recognizes the OVA peptide on $\mathrm{H}-2 \mathrm{~K}^{\mathrm{b}}$ (Figure 1C). Further, by analyzing OT-I proliferation in CD11c-diphtheria toxin receptor (DTA) mice [in which CD11c ${ }^{+}$ DCs are removable by diphtheria toxin (DT) treatment] inoculated with $\mathrm{OVA} / \mathrm{H}-2 \mathrm{~K}^{\mathrm{b}}$ tumor cells, the authors demonstrated that
DCs are essential for OT-I proliferation in response to the tumor cell-derived OVA peptide- $\mathrm{H}-2 \mathrm{~K}^{\mathrm{b}}$ complexes in vivo (35). Finally, Wakim and Bevan highlighted the importance of cross-dressing in mouse models of viral infection (29). The authors utilized irradiated $\left(\mathrm{K}^{\mathrm{d}} \times \mathrm{K}^{\mathrm{b}}\right) \mathrm{F} 1$ mice reconstituted with $\mathrm{K}^{\mathrm{d}} \mathrm{CD} 11 \mathrm{c}$-DTR bone marrow $(\mathrm{BM})$ cells, in which DCs have only $\mathrm{K}^{\mathrm{d}}$ and are removable by DT treatment. Following adoptive transfer of OT-I 


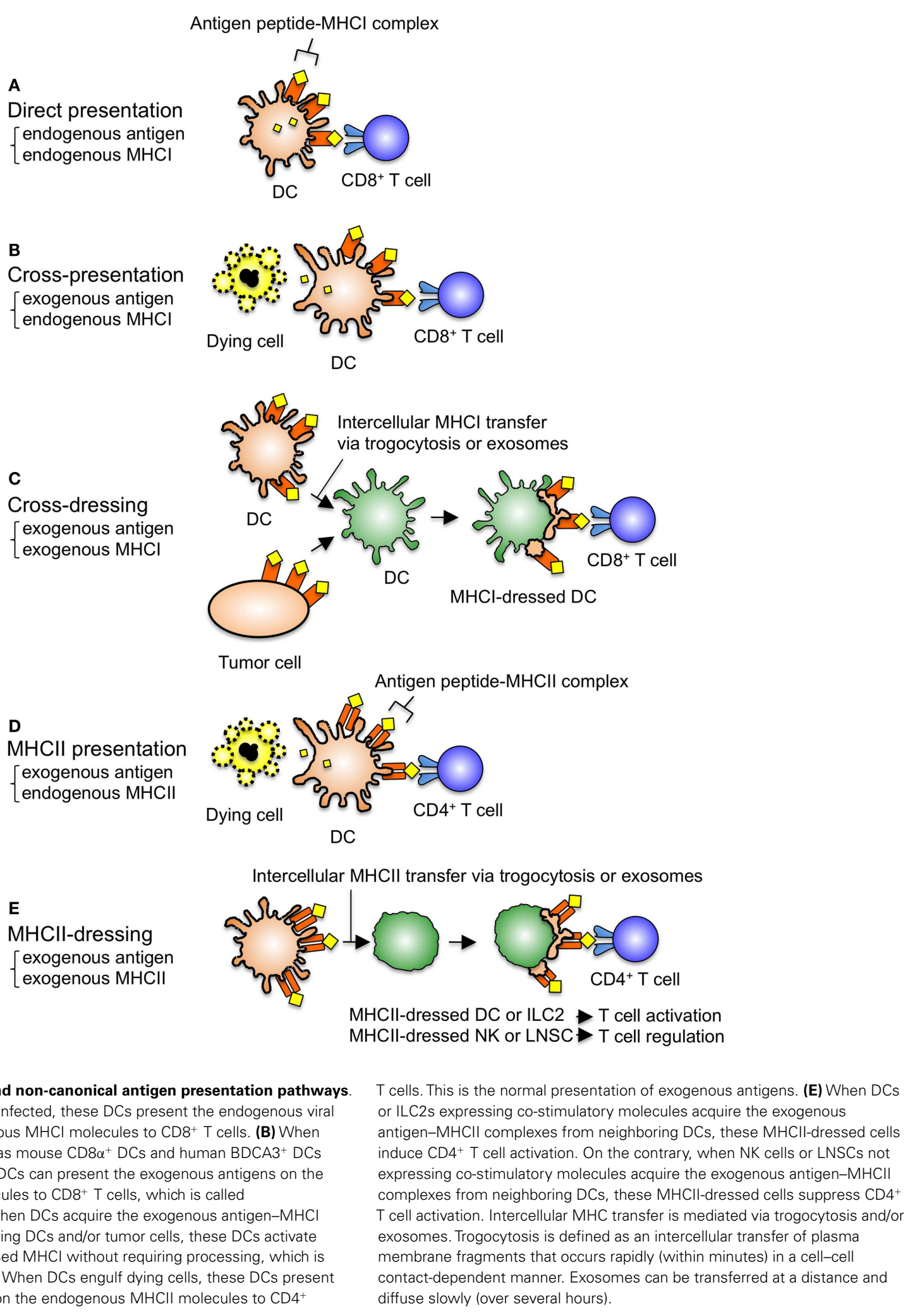

FIGURE 1 | Canonical and non-canonical antigen presentation pathways (A) When DCs are virally infected, these DCs present the endogenous viral antigens on the endogenous $\mathrm{MHCl}$ molecules to $\mathrm{CD}^{+} \mathrm{T}$ cells. (B) When certain DC subsets such as mouse CD $8 \alpha^{+}$DCs and human BDCA3 ${ }^{+}$DCs engulf dying cells, these DCs can present the exogenous antigens on the endogenous $\mathrm{MHCl}$ molecules to $\mathrm{CD}^{+} \mathrm{T}$ cells, which is called cross-presentation. (C) When DCs acquire the exogenous antigen-MHCl complexes from neighboring DCs and/or tumor cells, these DCs activate $\mathrm{CD}^{+} \mathrm{T}$ cells via the dressed $\mathrm{MHCl}$ without requiring processing, which is called cross-dressing. (D) When DCs engulf dying cells, these DCs present the exogenous antigens on the endogenous MHCII molecules to CD4
T cells. This is the normal presentation of exogenous antigens. (E) When DCs or ILC2s expressing co-stimulatory molecules acquire the exogenous antigen-MHCII complexes from neighboring DCs, these MHCll-dressed cells . from neighboring DCs, these MHCII-dressed cells suppress CD4t exosomes. Trogocytosis is defined as an intercellular transfer of plasma membrane fragments that occurs rapidly (within minutes) in a cell-cell diffuse slowly (over several hours) cells into these mice and infection with vesicular stomatitis virus expressing OVA, the authors demonstrated that DCs acquired the OVA peptide- $\mathrm{K}^{\mathrm{b}}$ complexes from the virally infected cells, and stimulated memory OT-I CD8 ${ }^{+}$T cells, but not naïve OT-I $\mathrm{CD}^{+} \mathrm{T}$ cells, in vivo. These results suggest that cross-dressing may contribute to effective anti-viral immune responses. 
Among mouse DC subsets, CD8 $\alpha^{-}$DCs show higher crossdressing of neighboring DC-derived MHCI compared with CD8 $\alpha^{+}$DCs (28-30), while CD8 $\alpha^{+}$DCs are essential for the cross-dressing of plasmid DNA vaccine antigens in vivo (36). This apparent discrepancy may be ascribed to the difference in type of donor cells (i.e., live DCs, dying tumor cells, etc.) that DCs acquire MHCI from. In addition to these conventional DCs, plasmacytoid DCs (pDCs) are a unique DC subset producing a large amount of type I interferon in response to microbial infection (62), and human pDCs have been also reported to acquire antigen-MHC complexes from tumor cells and to stimulate HLA-A2-restricted T cell proliferation (37).

The frequency of cross-dressing in vivo remains to be determined. A number of early reports investigating the crosspresentation pathway (Figure 1B) may have excluded the possibility of the recently emerged cross-dressing pathway (Figure 1C) $(57,58,63)$. For example, Kurts et al. engineered an elegant mouse model with which to demonstrate the cross-presentation pathway $(64,65)$. First, the authors generated the RIP (rat insulin promoter)-mOVA transgenic $\mathrm{K}^{\mathrm{b}}$ mouse that expresses membranebound form of OVA in pancreatic islet $\beta$ cells and renal proximal tubular cells. RIP-mOVA mice were lethally irradiated and received $\mathrm{K}^{\mathrm{b}} \mathrm{BM}$ cells or $\mathrm{K}^{\mathrm{bm} 1} \mathrm{BM}$ cells, where $\mathrm{K}^{\mathrm{bm} 1}$ is a $\mathrm{K}^{\mathrm{b}}$ mutant that does not present OVA peptide to OT-I cells. After adoptive transfer of OT-I cells into these mice, the authors observed the migration of OT-I cells into renal lymph nodes (LN) of RIP-mOVA mice receiving $\mathrm{K}^{\mathrm{b}} \mathrm{BM}$ cells, but not of the mice receiving $\mathrm{K}^{\mathrm{bm} 1} \mathrm{BM}$ cells $(64,65)$. These results clearly indicate that endogenous MHCI on BM-derived APCs is essential for exogenous antigen presentation. If cross-dressing occurred in this model, the authors would have observed OT-I cell migration in the RIP-mOVA mice receiving $\mathrm{K}^{\mathrm{bm} 1} \mathrm{BM}$ cells.

On the other hand, several early studies showed that crosspresentation was not required for priming of $\mathrm{CD}^{+} \mathrm{T}$ cells against some exogenous antigens $(33,66,67)$. For example, Kundig et al. reported that tumor cells directly induce CTLs in vivo, and host MHCI is not involved in this process (66). Wolfers et al. also observed that immunogenic tumor cells directly prime tumor-specific T cells in TAP (transporter associated with antigen presentation)-deficient mice (33). However, these studies do not exclude the possibility that host DCs acquire MHCI from tumor cells for the antigen presentation.

Taken together, it is possible that cross-dressing may occur in vivo only under pathological conditions such as during viral infection and cancer. Further, the phenomenon of cross-dressing may explain exogenous antigen presentation to $\mathrm{CD}^{+} \mathrm{T}$ cells in mouse models where cross-presentation does not occur.

It is also intriguing to address whether intercellular MHCI transfer impacts donor cell function. As described below, only a small percent of MHCI on donor cells can be transferred to recipient cells $(2,7)$. Thus, the donor cells seem to retain a sufficient amount of MHCI on their cell surface even after the transfer. However, interestingly, Chung et al. recently reported that lowavidity CTLs strip MHCI off target tumor cells via the mechanism of trogocytosis without killing, resulting in an interference with high-avidity CTLs in tumor lysis (8). It remains unknown whether donor DCs lose the antigen-presenting activity after the release of their MHC molecules to recipient DCs.

\section{ANTIGEN PRESENTATION BY MHCII-DRESSED CELLS}

MHCII is restrictedly expressed on professional APCs where it presents exogenous antigens to $\mathrm{CD} 4^{+} \mathrm{T}$ cells (Figure 1D) (68). In the thymus, intercellular MHCII transfer was observed between medullary thymic epithelial cells (mTECs) and DCs $(38,39)$. This process is proposed to increase the probability of autoreactive $\mathrm{T}$ cells encountering rare antigens for tolerance induction (40, 69). In the periphery, during the interaction between APCs and $\mathrm{CD}^{+}{ }^{+} \mathrm{T}$ cells, the TCR on the latter trogocytoses MHCII. Because $\mathrm{T}$ cells do not express co-stimulatory molecules, MHCII-dressed $\mathrm{CD}^{+}{ }^{+} \mathrm{T}$ cells induce tolerance in neighboring $\mathrm{CD} 4^{+} \mathrm{T}$ cells, terminating these $\mathrm{T}$ cell responses $(17,18)$. On the contrary, several reports show that $\mathrm{CD} 4^{+} \mathrm{T}$ cells trogocytose not only MHCII but also CD80, and these $\mathrm{CD}^{+}{ }^{+} \mathrm{T}$ cells dressed with MHCII and CD80 work as APCs for the amplification of $\mathrm{CD}^{+} \mathrm{T}$ cell proliferation (43-45). Together, existence of co-stimulatory molecules on MHCII-dressed cells determines these cell functions. Several recent studies reported that intercellular MHCII transfer occurs not only between DCs and T cells, but also between various cells such as DCs and DCs $(31,53,54,56)$, DCs and NK cells (50), DCs and lymph node stromal cells (LNSCs) (52), and DCs and group 2 innate lymphoid cells (ILC2s) (51) (Table 1).

The expression and function of MHCII on mouse NK cells have not been fully understood. We previously showed that mouse conventional NK cells do not synthesize MHCII, rather these cells rapidly acquire MHCII from co-cultured DCs (50). Moreover, NK cells dressed with the OVA peptide-MHCII complexes neither express nor acquire co-stimulatory molecules such as CD80 and CD86, and therefore, suppress but do not induce OT-II CD4 ${ }^{+}$ $\mathrm{T}$ cell proliferation, suggesting a negative regulation of acquired immunity by NK cells (Figure 1E) (50). NK cells also acquire MHCII from co-cultured B cells; however, the level of MHCII on these NK cells was lower than that on NK cells co-cultured with DCs, suggesting that NK cells preferentially acquire MHCII from DCs (50).

LNSCs have been considered to only play an architectural role in LN construction and homeostasis; however, it is now known that these cells play an important role in peripheral $\mathrm{T}$ cell tolerance (70). Dubrot et al. recently showed that LNSCs per se synthesize MHCII, but also acquire MHCII from DCs in vitro and in vivo (52). Like MHCII-dressed NK cells (50), MHCII-dressed LNSCs neither express nor acquire co-stimulatory molecules, resulting in promotion of $\mathrm{CD} 4^{+} \mathrm{T}$ cell apoptosis rather than proliferation. These data suggest that LNSCs maintain peripheral CD4 ${ }^{+} \mathrm{T}$ cell tolerance via DC-derived peptide-MHCII complexes in LNs (Figure 1E).

ILC2s are recently discovered innate lymphoid cells that produce IL-5, IL-9, and IL-13 and support type-2 immune responses such as allergy and anti-parasite immunity (71). Nevertheless, antigen presentation by ILC2 is not fully understood. Very recently, Oliphant et al. showed that ILC2s express MHCII and also acquire MHCII through trogocytosis in vivo (51). ILC2s also express CD80 and CD86 and polarize CD4 ${ }^{+}$T cells toward a Th2 phenotype by antigen presentation in conjunction with type- 2 cytokine 
production. Thus, the dressed MHCII may contribute to type-2 immune responses in vivo (Figure 1E).

Given that intercellular transfer of MHCII is observed between DCs and various immune cells, it would be intriguing to address the diffusion of APC-derived MHCII in vivo. In fact, such experiments may uncover a novel cell subset capable of activating or regulating $\mathrm{CD}_{4}{ }^{+} \mathrm{T}$ cells via the preformed antigen peptide-MHCII complexes.

\section{MECHANISM OF MHC TROGOCYTOSIS DO DC RECEPTORS MEDIATE MHC TROGOCYTOSIS?}

The molecular mechanism underlying the trogocytosis of MHC by $\mathrm{T}$ cells has been well studied $(3,6,7)$; however, the mechanism controlling this process in DCs remains to be identified. Of note, Martinez-Martin et al. have reported that TCRs trogocytose MHCI from APCs via small GTPases such as TC21 and RhoG previously known to be associated with phagocytosis. This finding led to the hypothesis that trogotytosis may actually represent immature phagocytosis (7). Therefore, DCs may trogocytose MHC by using phagocytic receptors. Harshyne et al. previously reported that plasma membrane transfer between live monkey DCs was inhibited in vitro by a polyanionic reagent, suggesting that scavenger receptors may contribute to the membrane transfer (60), although this has not been confirmed. Li et al. showed that mouse splenic CD $8 \alpha^{+}$DCs are essential for cross-dressing of plasmid DNA vaccine antigen in vivo (36). Of note, CD8 $\alpha^{+}$DCs are a unique DC subset that efficiently phagocytose apoptotic cells and perform cross-presentation $(57,58)$. In addition, these DCs have been reported to recognize dying cells via CLEC9A/DNGR-1 (72, 73), Treml4 (74), and Tim-3 (75); therefore, these receptors may acquire MHCI from dying cells. In contrast, Smyth et al., and Wakim and Bevan independently reported that splenic CD $8 \alpha^{-}$ DCs, rather than $\mathrm{CD} 8 \alpha^{+}$DCs, showed more efficient crossdressing of neighboring DC-derived MHCI (28-30). In these studies it remains unknown whether the cross-dressing activity is ascribed to the ability to acquire MHCI. Thus, although T cells solely use the TCR to acquire $\operatorname{MHC}(4,5,14)$, DCs may use different receptors to acquire MHCI from various donor cells.

Additionally, it is unknown if any membrane protein other than MHC is acquired by DCs, although it is unlikely that DCs specifically recognize and acquire only MHCI/II. More likely, DCs nibble a whole membrane fragment at the site of cell-cell contact similar to a model that has been proposed for $\mathrm{T}$ cell trogocytosis $(4,16)$. Indeed, the TCR on CD8 ${ }^{+} \mathrm{T}$ cells binds MHCI on DCs, and nibbles the MHCI-containing membrane fragments, in which MHCII is also contained $(3,49)$. Likewise, $\mathrm{CD} 4^{+} \mathrm{T}$ cells trogocytose not only MHCII but also MHCI from DCs through the bystander mechanism (23) (Table 1). Thus, any membrane proteins at the cell-cell contact area would be transferred to DCs. The reason only $\mathrm{MHC}$ molecules may appear to be transferred is probably because MHC molecules are highly expressed on donor cells and are easily detected. Only a small percent (at most 10\%) of highly expressed cell surface molecules on donor cells can be transferred to recipient cells, as shown by the fluorescence intensity of flow cytometry and confocal microscopy data in many reports $(2,7,29,35,36,50$, 76). Therefore, it is difficult to detect the trogocytosis of molecules with low expression on donor cells, even if trogocytosis occurs.
Identification of the DC receptor(s) and ligand(s) required for the trogocytosis of MHCI will resolve these issues.

\section{IS TROGOCYTOSIS DIFFERENT FROM EXOSOME-MEDIATED TRANSFER?}

Exosomes are nano-sized membrane vesicles released by a wide variety of cell types (15). Many reports have shown that MHCIbearing exosomes are secreted from APCs and several tumor cell lines, and that these exosomes play important roles in anti-tumor immunity $(15,77)$. For example, tumor-derived exosomes can activate $\mathrm{CD}^{+}{ }^{+} \mathrm{T}$ cells when co-cultured with DCs $(33,78)$. In these experiments, the exosomal MHCI is not critical, suggesting that tumor antigen alone, but not tumor-derived $\mathrm{MHCI}$, is required for DC-mediated antigen presentation $(33,78)$. Meanwhile, DCderived exosomes bear MHCI and co-stimulatory molecules, and per se are able to induce $\mathrm{CD}^{+} \mathrm{T}$ cell proliferation (15).

Wakim and Bevan conducted experiments to carefully address the possibility that cross-dressing is mediated via MHCI-bearing exosomes (29). In these experiments, it was observed that DCderived exosomes alone, but not those co-cultured with $\mathrm{H}-2 \mathrm{~K}^{\mathrm{bm} 1}$ DCs, induce OT-I CD ${ }^{+} \mathrm{T}$ cell proliferation, leading to the speculation that exosomes may be internalized by and degraded within DCs. Furthermore, the authors showed that DCs co-cultured at a distance (using a transwell system) lost cross-dressing activity, suggesting that the intercellular transfer of the peptide-MHCI complexes between DCs is mediated via cell-cell contact-dependent trogocytosis rather than exosomes (29).

MHCII-bearing exosomes are also secreted from DCs and possess functional capacity $(15,79)$. For instance, Théry et al. reported that DC-derived MHCII-bearing exosomes acquired by MHCII-deficient DCs can stimulate antigen-specific CD4 ${ }^{+} \mathrm{T}$ cell proliferation in vitro (54). Dubrot et al. observed that MHCII transfer from DCs to LNSCs is cell-cell contact-dependent, suggesting trogocytosis. Nevertheless, the authors do not exclude the possibility that DC-derived exosomes may also contribute to this process because LNSCs co-cultured with DC-derived exosomes also became MHCII-positive and activated CD4 ${ }^{+}$T cells (52).

As described above, trogocytosis was originally defined as an intercellular transfer of plasma membrane that occurs rapidly (within minutes) in a cell-cell contact-dependent manner. In contrast, exosomes can be transferred at a distance and diffuse slowly (over several hours) $(10,12)$. Indeed, the TCR and NK receptors acquire MHC and related molecules from donor cells within minutes in a cell-cell contact-dependent manner, and this does not occur when donor cells and recipient cells are co-cultured at a distance in a transwell plate $(2,7,50,76,80)$, which is typical of trogocytosis. However, acquisition of MHC by DCs takes several hours $(28,29,31,35,36)$. To make matters more complicated, Mittelbrunn et al. recently showed that $\mathrm{T}$ cells secrete exosomes when a functional immunological synapse is formed at the APC contact site, and that this release of exosomes is abrogated by a transwell culture system (81). Together, these reports make it difficult to discriminate between trogocytosis and exosome-mediated transfer. As there are a variety of types of exosomes and exosome-like microvesicles (15), it is reasonable to hypothesize that trogocytosis may actually be mediated via several unique mechanisms, and furthermore, that some instances of exosome transfer and trogocytosis may be mediated via a shared mechanism. 


\section{CONCLUSION}

There is no doubt that DCs play a crucial role in antigen processing and presentation. However, it was unforeseen that the antigen peptide-MHC complexes on DCs can be transferred to neighboring DCs or non-APCs where the preformed peptide-MHC complexes are involved in antigen-specific $\mathrm{T}$ cell activation without requirement for further processing. These MHC-dressed cells expressing or not expressing co-stimulatory molecules could contribute to $\mathrm{T}$ cell activation or suppression, respectively, which may play an important role in fine-tuning signals from DCs in vivo. As the occurrence of this transfer has been well established, the leading question remaining is how exactly the MHC molecules are transferred. It also remains unknown whether donor cellderived membrane fragments including MHC can be fused or are merely attached to the membrane of recipient cells. Identification of the molecular mechanisms underlying MHC trogocytosis and exosome transfer will enable us to perturb these pathways and further address the physiological relevance of non-canonical antigen presentation in vivo.

\section{ACKNOWLEDGMENTS}

This work was supported by a Grant-in-aid for Scientific Research on Innovative Areas from the Japan Society for the Promotion of Science (JSPS) and by a grant from the Takeda Science Foundation.

\section{REFERENCES}

1. Cone RE, Sprent J, Marchalonis JJ. Antigen-binding specificity of isolated cell-surface immunoglobulin from thymus cells activated to histocompatibility antigens. Proc Natl Acad Sci U S A (1972) 69:2556-60. doi:10.1073/pnas.69. 9.2556

2. Huang JF, Yang Y, Sepulveda H, Shi W, Hwang I, Peterson PA, et al. TCR-mediated internalization of peptide-MHC complexes acquired by T cells. Science (1999) 286:952-4. doi:10.1126/science.286.5441.952

3. Hwang I, Huang JF, Kishimoto H, Brunmark A, Peterson PA, Jackson MR, et al. $\mathrm{T}$ cells can use either $\mathrm{T}$ cell receptor or CD28 receptors to absorb and internalize cell surface molecules derived from antigen-presenting cells. J Exp Med (2000) 191:1137-48. doi:10.1084/jem.191.7.1137

4. Trambas CM, Griffiths GM. Delivering the kiss of death. Nat Immunol (2003) 4:399-403. doi:10.1038/ni0503-399

5. Sprent J. Swapping molecules during cell-cell interactions. Sci STKE (2005) 2005:e8. doi:10.1126/stke.2732005pe8

6. Hudrisier D, Aucher A, Puaux AL, Bordier C, Joly E. Capture of target cell membrane components via trogocytosis is triggered by a selected set of surface molecules on T or B cells. J Immunol (2007) 178:3637-47. doi:10.4049/jimmunol. 178.6.3637

7. Martinez-Martin N, Fernandez-Arenas E, Cemerski S, Delgado P, Turner M, Heuser J, et al. T cell receptor internalization from the immunological synapse is mediated by TC21 and RhoG GTPase-dependent phagocytosis. Immunity (2011) 35:208-22. doi:10.1016/j.immuni.2011.06.003

8. Chung B, Stuge TB, Murad JP, Beilhack G, Andersen E, Armstrong BD, et al. Antigen-specific inhibition of high-avidity $\mathrm{T}$ cell target lysis by low-avidity $\mathrm{T}$ cells via trogocytosis. Cell Rep (2014) 8:871-82. doi:10.1016/j.celrep.2014.06.052

9. Joly E, Hudrisier D. What is trogocytosis and what is its purpose? Nat Immunol (2003) 4:815. doi:10.1038/ni0903-815

10. Rechavi O, Goldstein I, Kloog Y. Intercellular exchange of proteins: the immune cell habit of sharing. FEBS Lett (2009) 583:1792-9. doi:10.1016/j.febslet.2009. 03.014

11. Smyth LA, Afzali B, Tsang J, Lombardi G, Lechler RI. Intercellular transfer of MHC and immunological molecules: molecular mechanisms and biological significance. Am J Transplant (2007) 7:1442-9. doi:10.1111/j.1600-6143.2007. 01816.x

12. Davis DM. Intercellular transfer of cell-surface proteins is common and can affect many stages of an immune response. Nat Rev Immunol (2007) 7:238-43. doi:10.1038/nri2020
13. Roda-Navarro P, Reyburn HT. Intercellular protein transfer at the NK cell immune synapse: mechanisms and physiological significance. FASEB J (2007) 21:1636-46. doi:10.1096/fj.06-7488rev

14. Dhainaut M, Moser M. Regulation of immune reactivity by intercellular transfer. Front Immunol (2014) 5:112. doi:10.3389/fimmu.2014.00112

15. Thery C, Ostrowski M, Segura E. Membrane vesicles as conveyors of immune responses. Nat Rev Immunol (2009) 9:581-93. doi:10.1038/nri2567

16. Dopfer EP, Minguet S, Schamel WW. A new vampire saga: the molecular mechanism of T cell trogocytosis. Immunity (2011) 35:151-3. doi:10.1016/j.immuni. 2011.08.004

17. Tsang JY, Chai JG, Lechler R. Antigen presentation by mouse CD4+ T cells involving acquired MHC class II:peptide complexes: another mechanism to limit clonal expansion? Blood (2003) 101:2704-10. doi:10.1182/blood-2002-04-1230

18. Helft J, Jacquet A, Joncker NT, Grandjean I, Dorothee G, Kissenpfennig A, et al. Antigen-specific T-T interactions regulate CD4 T cell expansion. Blood (2008) 112:1249-58. doi:10.1182/blood-2007-09-114389

19. Stinchcombe JC, Bossi G, Booth S, Griffiths GM. The immunological synapse of CTL contains a secretory domain and membrane bridges. Immunity (2001) 15:751-61. doi:10.1016/S1074-7613(01)00234-5

20. Machlenkin A, Uzana R, Frankenburg S, Eisenberg G, Eisenbach L, Pitcovski J, et al. Capture of tumor cell membranes by trogocytosis facilitates detection and isolation of tumor-specific functional CTLs. Cancer Res (2008) 68:2006-13. doi:10.1158/0008-5472.CAN-07-3119

21. Hudrisier D, Riond J, Mazarguil H, Gairin JE, Joly E. Cutting edge: CTLs rapidly capture membrane fragments from target cells in a TCR signaling-dependent manner. J Immunol (2001) 166:3645-9. doi:10.4049/jimmunol.166.6.3645

22. Ford McIntyre MS, Young KJ, Gao J, Joe B, Zhang L. Cutting edge: in vivo trogocytosis as a mechanism of double negative regulatory $\mathrm{T}$ cell-mediated antigen-specific suppression. J Immunol (2008) 181:2271-5. doi:10.4049/ jimmunol.181.4.2271

23. Xiang J, Huang H, Liu Y. A new dynamic model of CD ${ }^{+} \mathrm{T}$ effector cell responses via $\mathrm{CD}^{+} \mathrm{T}$ helper-antigen-presenting cells. J Immunol (2005) 174:7497-505. doi:10.4049/jimmunol.174.12.7497

24. Sjostrom A, Eriksson M, Cerboni C, Johansson MH, Sentman CL, Karre K, et al. Acquisition of external major histocompatibility complex class I molecules by natural killer cells expressing inhibitory Ly49 receptors. J Exp Med (2001) 194:1519-30. doi:10.1084/jem.194.10.1519

25. Carlin LM, Eleme K, McCann FE, Davis DM. Intercellular transfer and supramolecular organization of human leukocyte antigen $\mathrm{C}$ at inhibitory natural killer cell immune synapses. J Exp Med (2001) 194:1507-17. doi:10.1084/ jem.194.10.1507

26. Vanherberghen B, Andersson K, Carlin LM, Nolte-'t Hoen EN, Williams GS, Hoglund $\mathrm{P}$, et al. Human and murine inhibitory natural killer cell receptors transfer from natural killer cells to target cells. Proc Natl Acad Sci U S A (2004) 101:16873-8. doi:10.1073/pnas.0406240101

27. Zimmer J, Ioannidis V, Held W. H-2D ligand expression by Ly $49 \mathrm{~A}^{+}$natural killer (NK) cells precludes ligand uptake from environmental cells: implications for NK cell function. J Exp Med (2001) 194:1531-9. doi:10.1084/jem.194.10.1531

28. Smyth LA, Harker N, Turnbull W, El-Doueik H, Klavinskis L, Kioussis D, et al. The relative efficiency of acquisition of MHC:peptide complexes and crosspresentation depends on dendritic cell type. J Immunol (2008) 181:3212-20. doi:10.4049/jimmunol.181.5.3212

29. Wakim LM, Bevan MJ. Cross-dressed dendritic cells drive memory CD8 ${ }^{+}$ $\mathrm{T}$ cell activation after viral infection. Nature (2011) 471:629-32. doi:10.1038/ nature09863

30. Smyth LA, Hervouet C, Hayday T, Becker PD, Ellis R, Lechler RI, et al. Acquisition of MHC:peptide complexes by dendritic cells contributes to the generation of antiviral CD8 ${ }^{+} \mathrm{T}$ cell immunity in vivo. J Immunol (2012) 189:2274-82. doi:10.4049/jimmunol.1200664

31. Herrera OB, Golshayan D, Tibbott R, Salcido Ochoa F, James MJ, MarelliBerg FM, et al. A novel pathway of alloantigen presentation by dendritic cells. J Immunol (2004) 173:4828-37. doi:10.4049/jimmunol.173.8.4828

32. Andre F, Chaput N, Schartz NE, Flament C, Aubert N, Bernard J, et al. Exosomes as potent cell-free peptide-based vaccine. I. Dendritic cell-derived exosomes transfer functional MHC class I/peptide complexes to dendritic cells. J Immunol (2004) 172:2126-36. doi:10.4049/jimmunol.172.4.2126

33. Wolfers J, Lozier A, Raposo G, Regnault A, Thery C, Masurier C, et al. Tumor-derived exosomes are a source of shared tumor rejection antigens for CTL cross-priming. Nat Med (2001) 7:297-303. doi:10.1038/85438 
34. Russo V, Zhou D, Sartirana C, Rovere P, Villa A, Rossini S, et al. Acquisition of intact allogeneic human leukocyte antigen molecules by human dendritic cells. Blood (2000) 95:3473-7.

35. Dolan BP, Gibbs KD Jr., Ostrand-Rosenberg S. Dendritic cells cross-dressed with peptide MHC class I complexes prime CD8 ${ }^{+} \mathrm{T}$ cells. J Immunol (2006) 177:6018-24. doi:10.4049/jimmunol.177.9.6018

36. Li L, Kim S, Herndon JM, Goedegebuure P, Belt BA, Satpathy AT, et al. Crossdressed CD8alpha ${ }^{+} / \mathrm{CD}_{103}{ }^{+}$dendritic cells prime $\mathrm{CD}^{+} \mathrm{T}$ cells following vaccination. Proc Natl Acad Sci U S A (2012) 109:12716-21. doi:10.1073/pnas. 1203468109

37. Bonaccorsi I, Morandi B, Antsiferova O, Costa G, Oliveri D, Conte R, et al. Membrane transfer from tumor cells overcomes deficient phagocytic ability of plasmacytoid dendritic cells for the acquisition and presentation of tumor antigens. J Immunol (2014) 192:824-32. doi:10.4049/jimmunol.1301039

38. Humblet C, Rudensky A, Kyewski B. Presentation and intercellular transfer of self antigen within the thymic microenvironment: expression of the E alpha peptideI-Ab complex by isolated thymic stromal cells. Int Immunol (1994) 6:1949-58. doi:10.1093/intimm/6.12.1949

39. Millet V, Naquet P, Guinamard RR. Intercellular MHC transfer between thymic epithelial and dendritic cells. Eur J Immunol (2008) 38:1257-63. doi:10.1002/ eji.200737982

40. Koble C, Kyewski B. The thymic medulla: a unique microenvironment for intercellular self-antigen transfer. J Exp Med (2009) 206:1505-13. doi:10.1084/jem. 20082449

41. Osborne DG, Wetzel SA. Trogocytosis results in sustained intracellular signaling in $\mathrm{CD}^{+}$T cells. J Immunol (2012) 189:4728-39. doi:10.4049/jimmunol. 1201507

42. Wetzel SA, McKeithan TW, Parker DC. Peptide-specific intercellular transfer of MHC class II to $\mathrm{CD}^{+}{ }^{+} \mathrm{T}$ cells directly from the immunological synapse upon cellular dissociation. J Immunol (2005) 174:80-9. doi:10.4049/jimmunol. 174.1.80

43. Tatari-Calderone Z, Semnani RT, Nutman TB, Schlom J, Sabzevari H. Acquisition of CD80 by human T cells at early stages of activation: functional involvement of CD80 acquisition in T cell to T cell interaction. J Immunol (2002) 169:6162-9. doi:10.4049/jimmunol.169.11.6162

44. Zhou J, Tagaya Y, Tolouei-Semnani R, Schlom J, Sabzevari H. Physiological relevance of antigen presentasome (APS), an acquired $\mathrm{MHC} /$ costimulatory complex, in the sustained activation of $\mathrm{CD} 4^{+} \mathrm{T}$ cells in the absence of APCs. Blood (2005) 105:3238-46. doi:10.1182/blood-2004-08-3236

45. Game DS, Rogers NJ, Lechler RI. Acquisition of HLA-DR and costimulatory molecules by T cells from allogeneic antigen presenting cells. Am J Transplant (2005) 5:1614-25. doi:10.1111/j.1600-6143.2005.00916.x

46. Nolte-'t Hoen EN, Buschow SI, Anderton SM, Stoorvogel W, Wauben MH. Activated T cells recruit exosomes secreted by dendritic cells via LFA-1. Blood (2009) 113:1977-81. doi:10.1182/blood-2008-08-174094

47. Patel DM, Arnold PY, White GA, Nardella JP, Mannie MD. Class II MHC/peptide complexes are released from APC and are acquired by $\mathrm{T}$ cell responders during specific antigen recognition. J Immunol (1999) 163:5201-10.

48. Arnold PY, Mannie MD. Vesicles bearing MHC class II molecules mediate transfer of antigen from antigen-presenting cells to $\mathrm{CD}^{+}{ }^{+} \mathrm{T}$ cells. Eur J Immunol (1999) 29:1363-73. doi:10.1002/(SICI)1521-4141(199904)29:04<1363::AIDIMMU1363>3.0.CO;2-0

49. Romagnoli PA, Premenko-Lanier MF, Loria GD, Altman JD. CD8 T cell memory recall is enhanced by novel direct interactions with CD4 T cells enabled by MHC class II transferred from APCs. PLoS One (2013) 8:e56999. doi:10.1371/journal.pone.0056999

50. Nakayama M, Takeda K, Kawano M, Takai T, Ishii N, Ogasawara K. Natural killer (NK)-dendritic cell interactions generate MHC class II-dressed NK cells that regulate CD4 ${ }^{+}$T cells. Proc Natl Acad Sci U S A (2011) 108:18360-5. doi:10.1073/pnas.1110584108

51. Oliphant CJ, Hwang YY, Walker JA, Salimi M, Wong SH, Brewer JM, et al. MHCII-mediated dialog between group 2 innate lymphoid cells and $\mathrm{CD} 4^{+} \mathrm{T}$ cells potentiates type 2 immunity and promotes parasitic helminth expulsion. Immunity (2014) 41:283-95. doi:10.1016/j.immuni.2014.06.016

52. Dubrot J, Duraes FV, Potin L, Capotosti F, Brighouse D, Suter T, et al. Lymph node stromal cells acquire peptide-MHCII complexes from dendritic cells and induce antigen-specific CD4 ${ }^{+} \mathrm{T}$ cell tolerance. J Exp Med (2014) 211:1153-66. doi: $10.1084 /$ jem. 20132000
53. Segura E, Guerin C, Hogg N, Amigorena S, Thery C. CD8 ${ }^{+}$dendritic cells use LFA-1 to capture MHC-peptide complexes from exosomes in vivo. J Immunol (2007) 179:1489-96. doi:10.4049/jimmunol.179.3.1489

54. Théry C, Duban L, Segura E, Veron P, Lantz O, Amigorena S. Indirect activation of naive $\mathrm{CD}^{+} \mathrm{T}$ cells by dendritic cell-derived exosomes. Nat Immunol (2002) 3:1156-62. doi:10.1038/ni854

55. Dolan BP, Gibbs KD Jr., Ostrand-Rosenberg S. Tumor-specific CD4 ${ }^{+} \mathrm{T}$ cells are activated by "cross-dressed" dendritic cells presenting peptide-MHC class II complexes acquired from cell-based cancer vaccines. J Immunol (2006) 176:1447-55. doi:10.4049/jimmunol.176.3.1447

56. Markey KA, Koyama M, Gartlan KH, Leveque L, Kuns RD, Lineburg KE, et al. Cross-dressing by donor dendritic cells after allogeneic bone marrow transplantation contributes to formation of the immunological synapse and maximizes responses to indirectly presented antigen. J Immunol (2014) 192:5426-33. doi:10.4049/jimmunol.1302490

57. Heath WR, Belz GT, Behrens GM, Smith CM, Forehan SP, Parish IA, et al. Crosspresentation, dendritic cell subsets, and the generation of immunity to cellular antigens. Immunol Rev (2004) 199:9-26. doi:10.1111/j.0105-2896.2004.00142.x

58. Kurts C, Robinson BW, Knolle PA. Cross-priming in health and disease. Nat Rev Immunol (2010) 10:403-14. doi:10.1038/nri2780

59. Harshyne LA, Watkins SC, Gambotto A, Barratt-Boyes SM. Dendritic cells acquire antigens from live cells for cross-presentation to CTL. J Immunol (2001) 166:3717-23. doi:10.4049/jimmunol.166.6.3717

60. Harshyne LA, Zimmer MI, Watkins SC, Barratt-Boyes SM. A role for class A scavenger receptor in dendritic cell nibbling from live cells. J Immunol (2003) 170:2302-9. doi:10.4049/jimmunol.170.5.2302

61. Yewdell JW, Haeryfar SM. Understanding presentation of viral antigens to CD8 ${ }^{+}$ T cells in vivo: the key to rational vaccine design. Annu Rev Immunol (2005) 23:651-82. doi:10.1146/annurev.immunol.23.021704.115702

62. Reizis B, Colonna M, Trinchieri G, Barrat F, Gilliet M. Plasmacytoid dendritic cells: one-trick ponies or workhorses of the immune system? Nat Rev Immunol (2011) 11:558-65. doi:10.1038/nri3027

63. Joffre OP, Segura E, Savina A, Amigorena S. Cross-presentation by dendritic cells. Nat Rev Immunol (2012) 12:557-69. doi:10.1038/nri3254

64. Kurts C, Heath WR, Carbone FR, Allison J, Miller JF, Kosaka H. Constitutive class I-restricted exogenous presentation of self antigens in vivo. J Exp Med (1996) 184:923-30. doi:10.1084/jem.184.3.923

65. Kurts C, Kosaka H, Carbone FR, Miller JF, Heath WR. Class I-restricted crosspresentation of exogenous self-antigens leads to deletion of autoreactive CD8 ${ }^{+}$ T cells. J Exp Med (1997) 186:239-45. doi:10.1084/jem.186.2.239

66. Kundig TM, Bachmann MF, DiPaolo C, Simard JJ, Battegay M, Lother H, et al. Fibroblasts as efficient antigen-presenting cells in lymphoid organs. Science (1995) 268:1343-7. doi:10.1126/science.7761853

67. Schuler T, Blankenstein T. Cutting edge: $\mathrm{CD}^{+}$effector T cells reject tumors by direct antigen recognition but indirect action on host cells. J Immunol (2003) 170:4427-31. doi:10.4049/jimmunol.170.9.4427

68. Ting JP, Trowsdale J. Genetic control of MHC class II expression. Cell (2002) 109(Suppl):S21-33. doi:10.1016/S0092-8674(02)00696-7

69. Klein L, Hinterberger M, Wirnsberger G, Kyewski B. Antigen presentation in the thymus for positive selection and central tolerance induction. Nat Rev Immunol (2009) 9:833-44. doi:10.1038/nri2669

70. Fletcher AL, Malhotra D, Turley SJ. Lymph node stroma broaden the peripheral tolerance paradigm. Trends Immunol (2011) 32:12-8. doi:10.1016/j.it.2010. 11.002

71. Spits H, Artis D, Colonna M, Diefenbach A, Di Santo JP, Eberl G, et al. Innate lymphoid cells - a proposal for uniform nomenclature. Nat Rev Immunol (2013) 13:145-9. doi:10.1038/nri3365

72. Sancho D, Joffre OP, Keller AM, Rogers NC, Martinez D, Hernanz-Falcon P, et al. Identification of a dendritic cell receptor that couples sensing of necrosis to immunity. Nature (2009) 458:899-903. doi:10.1038/nature07750

73. Zelenay S, Keller AM, Whitney PG, Schraml BU, Deddouche S, Rogers NC, et al. The dendritic cell receptor DNGR-1 controls endocytic handling of necrotic cell antigens to favor cross-priming of CTLs in virus-infected mice. J Clin Invest (2012) 122:1615-27. doi:10.1172/JCI60644

74. Hemmi H, Zaidi N, Wang B, Matos I, Fiorese C, Lubkin A, et al. Treml4, an Ig superfamily member, mediates presentation of several antigens to $\mathrm{T}$ cells in vivo, including protective immunity to HER2 protein. JImmunol (2012) 188:1147-55. doi:10.4049/jimmunol.1102541 
75. Nakayama M, Akiba H, Takeda K, Kojima Y, Hashiguchi M, Azuma M, et al. Tim-3 mediates phagocytosis of apoptotic cells and cross-presentation. Blood (2009) 113:3821-30. doi:10.1182/blood-2008-10-185884

76. Nakamura K, Nakayama M, Kawano M, Amagai R, Ishii T, Harigae H, et al. Fratricide of natural killer cells dressed with tumor-derived NKG2D ligand. Proc Natl Acad Sci U S A (2013) 110:9421-6. doi:10.1073/pnas.1300140110

77. Pitt JM, Charrier M, Viaud S, Andre F, Besse B, Chaput N, et al. Dendritic cellderived exosomes as immunotherapies in the fight against cancer. J Immunol (2014) 193:1006-11. doi:10.4049/jimmunol.1400703

78. Andre F, Schartz NE, Movassagh M, Flament C, Pautier P, Morice P, et al. Malignant effusions and immunogenic tumour-derived exosomes. Lancet (2002) 360:295-305. doi:10.1016/S0140-6736(02)09552-1

79. Gutierrez-Vazquez C, Villarroya-Beltri C, Mittelbrunn M, Sanchez-Madrid F. Transfer of extracellular vesicles during immune cell-cell interactions. Immunol Rev (2013) 251:125-42. doi:10.1111/imr.12013

80. Caumartin J, Favier B, Daouya M, Guillard C, Moreau P, Carosella ED, et al. Trogocytosis-based generation of suppressive NK cells. EMBO J (2007) 26:1423-33. doi:10.1038/sj.emboj.7601570

81. Mittelbrunn M, Gutierrez-Vazquez C, Villarroya-Beltri C, Gonzalez S, SanchezCabo F, Gonzalez MA, et al. Unidirectional transfer of microRNA-loaded exosomes from T cells to antigen-presenting cells. Nat Commun (2011) 2:282. doi:10.1038/ncomms1285

Conflict of Interest Statement: The author declares that the research was conducted in the absence of any commercial or financial relationships that could be construed as a potential conflict of interest.

Received: 26 September 2014; accepted: 15 December 2014; published online: 05 January 2015.

Citation: Nakayama M (2015) Antigen presentation by MHC-dressed cells. Front. Immunol. 5:672. doi: 10.3389/fimmu.2014.00672

This article was submitted to Antigen Presenting Cell Biology, a section of the journal Frontiers in Immunology.

Copyright (c) 2015 Nakayama. This is an open-access article distributed under the terms of the Creative Commons Attribution License (CC BY). The use, distribution or reproduction in other forums is permitted, provided the original author(s) or licensor are credited and that the original publication in this journal is cited, in accordance with accepted academic practice. No use, distribution or reproduction is permitted which does not comply with these terms. 